\title{
Review Methods for Estimating Loss of Life from Floods due to Dam Failure
}

\author{
Fatin Faiqa Norkhairi ${ }^{1 *}$, Sivadass Thiruchelvam ${ }^{2}$, Hasril Hasini ${ }^{3}$ \\ Institute of Energy Infrastructure \\ 123 Universiti Tenaga Nasional Jalan IKRAM-UNITEN, \\ 43000 Kajang, Selangor, Malaysia \\ *Corresponding author E-mail: Fatin.Faiqa@uniten.edu.my
}

\begin{abstract}
Dam is known as well build structure that stored high volume of water for various purposes such as irrigation, water supply and electricity generation. With the multiple usage of dam towards the nation and civilization, the dam should be properly examined so that it will not cause extreme effect in sociology, economics and environmental. However, dam may experience a failure due to many reasons. The aftermath of dam failure especially in term of loss of life could leave detrimental effects on human, properties as well as environment. Therefore, this paper provides a systematic review on the existing methods to estimate the loss of life due to the dam failure. Throughout the years, many improvements have been made to give better estimation for loss of life. Such prediction is very important for disaster planning by authorities.
\end{abstract}

Keywords: Dam failure; Floods; Loss of life; Mitigation; Risk assessment

\section{Introduction}

Dam which is functionally known as water supply, irrigation and hydropower. As the civilization develop and the demand for water increase, dam have specifically constructed as water supply, irrigation, flood control, navigation, recreation and hydropower. Dam is known to be large made by the concrete which has weight to act as a strength. Although dam may have a large size and have regular inspection by their workers but the potential to have a failure cannot be avoided. Dam failure is considered as one of the major events that hold the extreme consequences in environment, economy and the worst case is loss of life. Throughout the history, one of the famous dam failure happened was Teton Dam which caused 771 homes or mobile homes were destroyed, 3002 homes were damaged, 16650 livestock was lost, approximately $\$ 400$ million property damage and 11 human have lost their life were reported $[1,2]$. The Teton Dam has a maximum height of 305 feet and filled up by water up to 356 million cubic [3]. The dam failure is caused by major leaking near the northwest abutment of the dam and caused 80 gallon of water to be released [4]. The dam which was built by Bureau of Reclamation, collapsed when it is completed and being filled up with water for the first time. Recently, another dam failure has occured in Laos which caused at least 26 casualty, hundreds of people were missing and many were displaced. The root causes of the dam to breach was due to the heavy rain as well as attributable to shoddy construction. On July 23, the Xe-Pian Xe-Namnoy dam which was under construction since 2013 has ruptured causing 5 billion cubic water were released [5]. It causes a massive flooding and swept away the villages at the downstream.

In Malaysia, dam failure have never been occurred throughout the history. However, the water release from Sultan Abu Bakar Dam Cameron Highlands in 2013 caused three people killed, nearly 100 houses destroyed and thirty-eight people from 80 families to be placed at Ringlet Community Hall [6]. This proves that even though it involves small scale of water release, we could not rule out the possibility of catastrophic outcome.

From the aforementioned case history, the loss of life become severe when the height of dam is high (more than 100 feet) and the capacity of the water is large (more than 50,000 acre feet). If the dam failure occur, people at the downstream area near the dam will have greater effect compare to the other areas. This is because i) peak dam failure that discharge will immediately flow to downstream area, ii) the longer the distance of downstream, the higher the stream flow capacity iii) higher flood velocity is a result from a steeper river gradient from the dam.

This review paper focuses on the methods to estimate the loss of life resulting from the dam failure. According to Jonkman et al. [7] these methods generally use to identify the consequences of flooding and the result can be used in flood risk and as a mitigation plans. The objective of this review paper is to give a comprehensive review on different types of methods in estimating the loss of life due to dam failure. A literature review were conducted to identify the methods for loss of life due to dam failure

\section{Loss of Life Models for Dam Failure}

Over the years, several models have been developed to improve some of the extreme scenario and to build better estimation of loss of life. A comprehensive review due to loss of life for dam failure have been made before and these are some of the important methods that can be used. 


\subsection{DSO-99-06 Procedure}

This methodology is developed by Graham [8] to estimate the loss of life from the dam failure. The procedure is based on the statistical analysis and history of dam failure, flash flood and floods which were located in the United States. The fatality rates were based on the result of analysis from 16 dam failure and 450 deaths around the world [9]. The fatality rates were recommended based on the severity of the flood, warning siren or signs and the understanding by the population on flood severity [7]. The initiating of dam failure warning would be the general guidance to estimate the loss of life. Several factors may influence the estimation including the dam surveillance and monitoring and dam specific emergency action plans.

\subsubsection{Concept of DSO-99-06 Procedure}

Flood severity, warning time and degree of understanding of flood severity are main variables used for the outcome of the dam failure. Initiated of dam failure warning is important part to estimate the loss of life as the time where safety officers begin to inform the public on the dam failure risk and start to evacuate. If the dam failure warning sirens fail to be disseminates to the public, the loss of life may be increase. This indicates that public does not receive the warning signals. Warning system is usually used as risk mitigation measures which provide information on time and future events that can minimize the loss of life and damages $[10,11]$. The warning categories associated in this procedures use the concepts of 'none' (<15 min), 'some' (15-60 min), and 'adequate' $(>60 \mathrm{~min})$ [7]. The level of understanding in flood severity is depends on the warning received by the public. Therefore, the usage of verbal descriptors might be better to be received compare to the usage of actual number range. To increase the level of understanding on flood severity in public, it leads to increase the awareness in public to trigger their condition if dam failure occur. The consequences of the dam failure may be vary depending level of severity and the understanding of flood severity. However, awareness program such as Community based-disaster risk management is a chance to increase the level of understanding especially to the potentially affected public about dam failure thus reduce the loss of life [11]. Table 1 below shows the recommended fatality rates to estimate loss of life from dam failure.

Table 1: Recommended Fatality Rates for Estimating Loss of Life Resulting from Dam Failure (Source: Bureau of Reclamation, DSO-99-06)

\begin{tabular}{|c|c|c|c|c|}
\hline \multirow[t]{2}{*}{$\begin{array}{c}\text { Flood } \\
\text { Severity }\end{array}$} & \multirow[t]{2}{*}{$\begin{array}{l}\text { Warning } \\
\text { Time } \\
\text { (Minutes) }\end{array}$} & \multirow[t]{2}{*}{$\begin{array}{l}\text { Flood Severity } \\
\text { Understanding }\end{array}$} & \multicolumn{2}{|c|}{$\begin{array}{l}\text { Fatality rates } \\
\text { (Fraction of people at risk } \\
\text { projected to die) }\end{array}$} \\
\hline & & & Suggested & $\begin{array}{c}\text { Suggested } \\
\text { range }\end{array}$ \\
\hline \multirow[t]{5}{*}{ HIGH } & $\begin{array}{l}\text { No warn- } \\
\text { ing }\end{array}$ & Not applicable & 0.75 & $0.30-1.00$ \\
\hline & \multirow[t]{2}{*}{15 to 60} & Vague & \multirow{4}{*}{\multicolumn{2}{|c|}{$\begin{array}{l}\text { Use the values shown } \\
\text { above and apply to the } \\
\text { number of people who } \\
\text { remain in the dam failure } \\
\text { floodplain after warning } \\
\text { are issued. No guidance is } \\
\text { provided on how many } \\
\text { people will remain in the } \\
\text { floodplain. }\end{array}$}} \\
\hline & & Precise & & \\
\hline & \multirow{2}{*}{$\begin{array}{c}\text { More than } \\
60\end{array}$} & Vague & & \\
\hline & & Precise & & \\
\hline \multirow[t]{5}{*}{ MEDIUM } & $\begin{array}{l}\text { No warn- } \\
\text { ing }\end{array}$ & Not applicable & 0.15 & $0.03-0.35$ \\
\hline & 15 to 60 & Vague & 0.04 & $0.01-0.08$ \\
\hline & & Precise & 0.02 & $\begin{array}{c}0.005- \\
0.04\end{array}$ \\
\hline & $\begin{array}{c}\text { More than } \\
60\end{array}$ & Vague & 0.03 & $\begin{array}{c}0.005- \\
0.06 \\
\end{array}$ \\
\hline & & Precise & 0.01 & $\begin{array}{c}0.002- \\
0.02 \\
\end{array}$ \\
\hline \multirow[t]{2}{*}{ LOW } & $\begin{array}{l}\text { No warn- } \\
\text { ing }\end{array}$ & Not applicable & 0.01 & $0.0-0.02$ \\
\hline & 15 to 60 & Vague & 0.007 & $0.0-0.015$ \\
\hline
\end{tabular}

\begin{tabular}{|c|c|c|c|c|}
\hline \multirow{4}{*}{} & & Precise & 0.002 & $0.0-0.004$ \\
\cline { 2 - 5 } & More than & Vague & 0.0003 & $0.0-$ \\
60 & & & 0.0006 \\
\cline { 2 - 5 } & & Precise & 0.0002 & $0.0-$ \\
& & & 0.0004 \\
\hline
\end{tabular}

The loss of life from dam failure may directly affected by floodwater but also may indirectly affected cause by injury or illness such as heart attack during the evacuation [12]. From the Table 1 above, the low severity of flooding with the excellent warning gave the suggested fatality rates of 0.0002 which represents 1 death for every 5000 people at risk. Repeated dam failure warning and the usage of social media in disseminating and communicating during the critical time [13] can help in providing convincing dangerous situations. This can result in higher evacuation rates and resulting the lower fatality rate. The case history data used to develop DSO-99-06, data loss of life from the road network or highway congestion does not countable. Meaning that if there is loss of life due to the heavy traffic network during the evacuation is not included. This type loss of life may consider as an indirect impact as public lost their way to save their life. Roads may be blocked by the flood impacted the ability to evacuate as their road network maybe destroyed.

\subsubsection{Application of DSO-99-06 Procedure}

The method was applied to the Dongwushi reservoir in Hebei province. The reservoir is built with the height of $34.1 \mathrm{~m}$, the water surface level is $106.18 \mathrm{~m}$ and storage volume $162 \times 10^{6} \mathrm{~m}^{3}$ [14] The dam failure occur because of the overtopping. By using the DSO-99-06 procedure, the estimated loss of life was calculate. Figure 1 below shows the maximum outflow of water which the location of downstream have been divided into 7 sections.

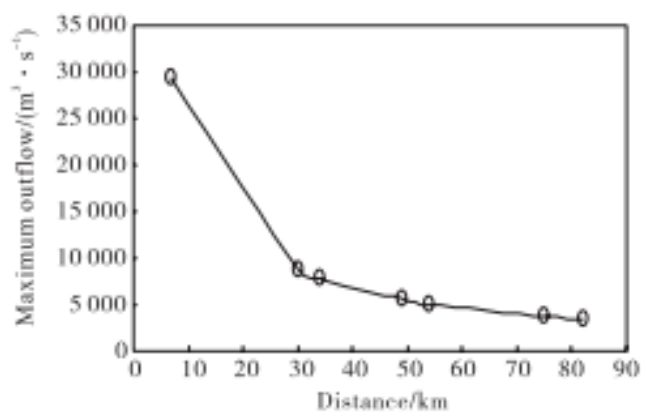

Fig. 1: Maximum outflow of calculation section (Adopted from: Sun, Y., et al, 2010).

From the figure above, the maximum outflow decrease as the distance from the dam increase. By using the reference from the Table 1, the estimated loss of life is tabulated in the Table 2 below.

Table 2: Losses of dam failure of different conditions (Source: Sun, Y., et

\begin{tabular}{|c|c|c|c|c|c|c|}
\hline $\begin{array}{c}\text { Sit } \\
\mathrm{e}\end{array}$ & $\begin{array}{c}\text { Flood } \\
\text { severity }\end{array}$ & $\begin{array}{c}\text { WT/ } \\
\mathrm{h}\end{array}$ & $\begin{array}{c}\text { Flood } \\
\text { severity } \\
\text { under- } \\
\text { standing }\end{array}$ & $\begin{array}{c}\text { Fatality } \\
\text { rate }\end{array}$ & $\begin{array}{c}\text { Popula- } \\
\text { tion at } \\
\text { Risk }\end{array}$ & LOL \\
\hline \multirow[t]{2}{*}{1} & \multirow[t]{2}{*}{$\begin{array}{l}\text { Medi- } \\
\text { um }\end{array}$} & $\begin{array}{r}0.25 \\
-1.0 \\
\end{array}$ & $\begin{array}{l}\text { Vague } \\
\text { Precise }\end{array}$ & $\begin{array}{c}0.01 \\
0.005 \\
\end{array}$ & 630000 & $\begin{array}{l}6300 \\
3150 \\
\end{array}$ \\
\hline & & $>1.0$ & $\begin{array}{l}\text { Vague } \\
\text { Precise }\end{array}$ & $\begin{array}{c}0.005 \\
0.02 \\
\end{array}$ & & $\begin{array}{l}3150 \\
1250\end{array}$ \\
\hline \multirow[t]{2}{*}{2} & \multirow[t]{2}{*}{ Low } & $\begin{array}{r}0.25 \\
-1.0 \\
\end{array}$ & $\begin{array}{l}\text { Vague } \\
\text { Precise }\end{array}$ & $\begin{array}{l}0.007 \\
0.002 \\
\end{array}$ & 400000 & $\begin{array}{c}2800 \\
800 \\
\end{array}$ \\
\hline & & $>1.0$ & $\begin{array}{l}\text { Vague } \\
\text { Precise }\end{array}$ & $\begin{array}{l}0.0003 \\
0.0002 \\
\end{array}$ & & $\begin{array}{c}120 \\
80\end{array}$ \\
\hline \multirow[t]{2}{*}{3} & \multirow[t]{2}{*}{ Low } & $\begin{array}{r}0.25 \\
-1.0 \\
\end{array}$ & $\begin{array}{l}\text { Vague } \\
\text { Precise }\end{array}$ & $\begin{array}{l}0.007 \\
0.002 \\
\end{array}$ & 370000 & $\begin{array}{c}2590 \\
740 \\
\end{array}$ \\
\hline & & $>1.0$ & $\begin{array}{l}\text { Vague } \\
\text { Precise }\end{array}$ & $\begin{array}{l}0.0003 \\
0.0002\end{array}$ & & $\begin{array}{c}111 \\
74 \\
\end{array}$ \\
\hline 4 & Low & 0.25 & Vague & 0.007 & 310000 & 2170 \\
\hline
\end{tabular}




\begin{tabular}{|c|c|c|c|c|c|c|}
\hline & & -1.0 & Precise & 0.002 & & 620 \\
\cline { 3 - 7 } & & $>1.0$ & Vague & 0.0003 & & 93 \\
& & Precise & 0.0002 & & 62 \\
\hline 5 & \multirow{2}{*}{ Low } & 0.25 & Vague & 0.007 & 820000 & 5740 \\
& & -1.0 & Precise & 0.002 & & 1640 \\
\cline { 3 - 7 } & & $>1.0$ & Vague & 0.0003 & & 246 \\
& & Precise & 0.0002 & & 164 \\
\hline 6 & \multirow{2}{*}{ Low } & 0.25 & Vague & 0.007 & 410000 & 2870 \\
& & -1.0 & Precise & 0.002 & & 820 \\
\cline { 3 - 7 } & & $>1.0$ & Vague & 0.0003 & & 123 \\
& & Precise & 0.0002 & & 82 \\
\hline 7 & \multirow{2}{*}{ Low } & 0.25 & Vague & 0.007 & 250000 & 1750 \\
& & -1.0 & Precise & 0.002 & & 500 \\
\cline { 3 - 7 } & & $>1.0$ & Vague & 0.0003 & & 75 \\
& & & Precise & 0.0002 & & 50 \\
\hline
\end{tabular}

From the table above, the flood severity in the first table is the largest due to the location that near the dam. The total loss of life also bigger compare to the other column. The loss of life also may be different compare because it depends on the warning time and the understanding on flood severity. When the warning time was between $0.25-1.0$ the flood understanding become vague and the total loss of life is higher. Therefore, the dam safety and flood risk management need to be taken care seriously. If the dam failure occur it may affect the population and the environment.

\subsection{Life Safety Model}

Life Safety model is a prototype piece created by the British Columbia Hydro (BC Hydro) in Canada [7, 15]. The DSO-99-06 procedure above use the statistical approach based on the history of dam failure. This LSM prototype use the approach of the interaction between the hydrodynamics (flood hazards) and the 'agents' which include people, building and vehicles. The data required including the population people at risk (PAR), flood depths and velocity, and the road network [15]. From this form of analysis, two output may be produce by the model which is i) estimation of loss of life; ii) the emergency planning and loss of life mitigation.

The Figure 2 below shows the concept of LSM which shows the interaction between the dynamics and its 'agents'.

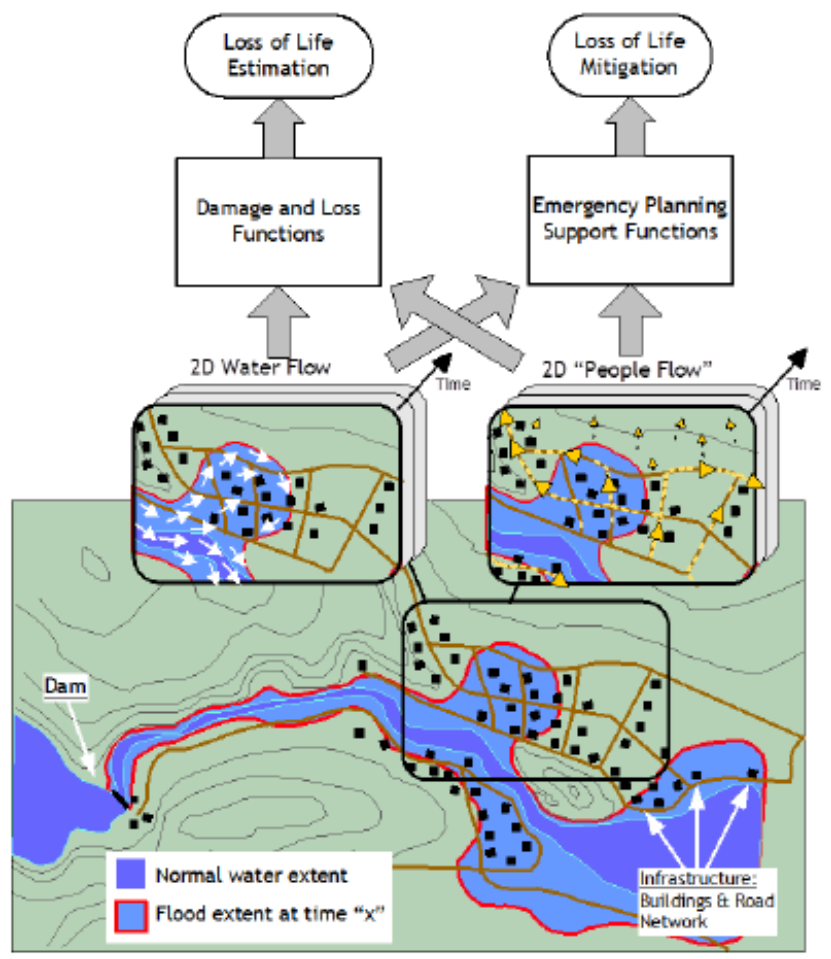

Fig. 2: LSM Concept (Source: LSM Users Guidance v3)
The conceptual of LSM combines the existing technologies such as GIS, 2D hydraulic model and human behavior. This combination creates clear understanding on the location and variation of individuals at the flood impact zone.

\subsubsection{Concept of Life Safety Model}

In the virtual world created in LSM, the population data including the people at risks, building and vehicles is refer as 'People's World'. The most important 'agents' in this model is people which the purpose of this model to reduce the loss of life if dam failure occur. Logic configuration is the basic principal used in LSM where it consider the individual behavior when they encounter the flood wave. It depends on individual decision on how they are trying to save their life and find the safe haven [15]. Figure 3 below shows the basic configuration and flood wave using the LSM. It shows the physical context and variables to build the LSM. Considering that the flood wave have heavily inundated to the area. Therefore it carrying the flood depth, (d) and the velocity (v) or dv. The basic concept of the LSM is that each object (people, vehicles, building) has resistant, $\mathrm{R}$ to withstand the flood loading, S. The state changes to DESTROYED when $\mathrm{R}<\mathrm{S}$. Flood wave can cause the state changes through toppling, instantaneous loss or cumulative loss. Figure 4 shows the generic example of loss function used in LSM. The flood severity can be determined by the DV (depth $\mathrm{x}$ velocity; $\mathrm{m}^{2} / \mathrm{s}$ ) value. The higher the DV value, the higher the flood severity will be experience. The value of DV can be obtained from the 2D hydraulic model that can be used to develop and map the boundaries to incorporate the flood severity. The vector elements in the LSM is toppling, floating an instantaneous loss. As the concepts of LSM depends on the interaction between the dynamics and its 'agents', LSM has the ability in developing several scenario to save the individual life and access the outcome from the scenario [16].

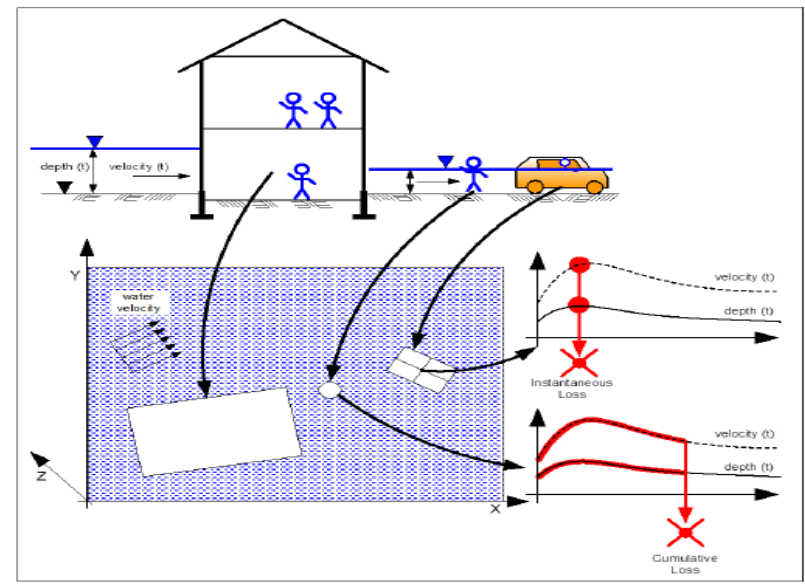

Fig. 3: Basic configuration and flood wave (Source: LSM Users Guide v3)

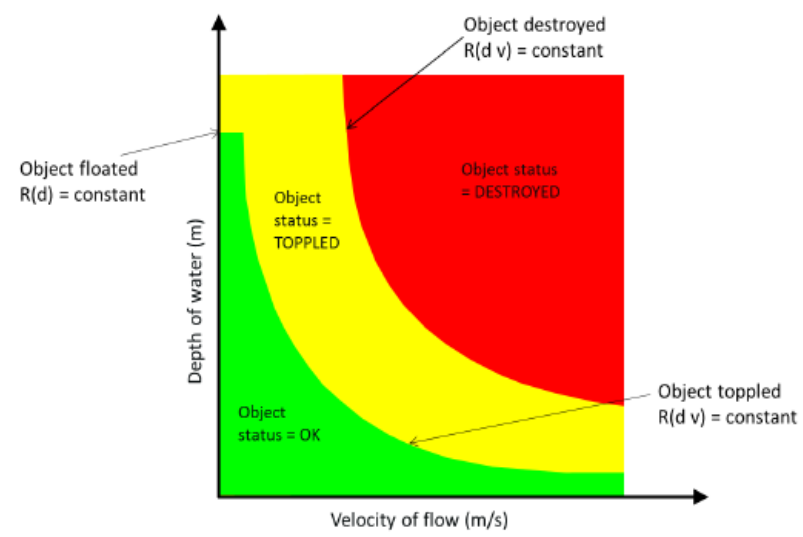

Fig. 4: Generic example of loss function in LSM (Source: LSM Users Guide v3) 
A person loss being subjected to flood water will cause the person to be toppled or deceased. Toppled individual is considered to have low strength and to be deceased when the strength of individual become weak. The person that aware of the flood will move towards the safe haven and it considered being safe. There is a lot of criteria when considering the toppled or deceased person which one of the criteria is the depth of flood water. They become unstable in water with the sufficiently high $\mathrm{dv}$. The drowning of a person can be categorized in three different ways whether if the person stayed in the destroyed building, person walking in greatly high $\mathrm{dv}$ and their vehicle being drowned in the water (during evacuation) [7]. When the flood wave strikes, the LSM can determine whether the building 'Standing' or 'Destroyed'. Building can be 'Destroyed' in three conditions which are i) building experience high depth and velocity; ii) water depth greater than the height of building; iii) the initial structure value turn below the critical level. As the flood wave impacts particular building, the hydrostatic force, momentum of moving water may affect the structure thus leading to weakening of the structure itself.

During the evacuation, public may evacuate to safe haven by using their vehicles. The interaction between flood and vehicles can be estimated either it will be floating or toppled based on the flood depth and velocity. For vehicles, toppled is the condition when the person in the vehicles considered to be deceased. The travel to the safe haven itself is one of the factor that can contribute to reducing or increasing number of loss of life road or segment. However, it also can contribute in increasing number of loss of life if heavy traffic occur during the evacuation.

\subsubsection{Application of LSM to Malpasset Dam Disaster}

Malpasset dam is located at Reyran River Valley in southern France, $12 \mathrm{~km}$ from the upstream town of Frejus. The dam was made up to $66.5 \mathrm{~m}$ high with crest length of $223 \mathrm{~m}$ [17]. On 2 December 1959, the dam suddenly failed to function because of the water pressure on the rock and the nature of the rock causing the dam to release 55 million $\mathrm{m}^{3}$ of water [18]. The total fatalities caused by the dam failure is 423 and most fatalities occured at the downstream township of Frejus which has total population at risk about 6000 people $[18,19]$. The dam failure at the Malpasset dam was simulated with Life Safety model due to i) Available data for dam break including the calibrated, two dimensional, hydrodynamics data of flood wave; ii) Available data for 1:400 scale physical model taken by EDF (Electricite de France) on 1964; iii) Reliable data record for population at risk and people impacted by flood.

Telemac 2 dimensional (2D) model was used as a hydraulic model to simulate the dam breach flood. To create the flood event, the new develop topographic and infrastructure data need to set back to the year of 1959. All the data such as aerial photograph, oblique airbone photos and local map was needed to approximate the buildings and road network at time of 1959 [20].

The flood zone has been broken down into four impacted zones as shown in figure 4 below.

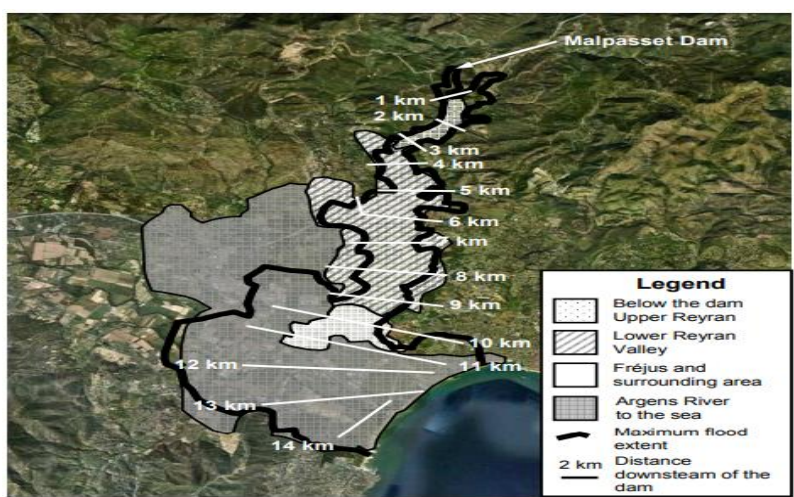

Fig. 5: Malpasset Impact zone (Sources: Lence, B., et al, 2011)
In order to estimate the loss of life the model input parameters were used such as family size, building and individual strength, building evacuation time, flood awareness related to the depth of flood water and building and individual strength reduction factor. It is possible to determine the suitable value for each parameter. However the results of the estimated casualty is approximately to the actual loss [20]. Table 2 shows the comparison of both estimation and actual loss of life at the Malpasset dam.

Table 2: Results of loss of life at Malpasset Dam (Adopted from: Lence, B., et al, 2011)

\begin{tabular}{|c|c|c|}
\hline & Loss of life & Building destroyed \\
\hline $\begin{array}{c}\text { Estimated with Life } \\
\text { Safety Model }\end{array}$ & 424 & 151 \\
\hline Actual number & $423-500$ & 158 \\
\hline
\end{tabular}

\subsection{DSO-99-06 vs LSM}

DSO-99-06 and Life Safety Model (LSM) both are known as tools that used to estimate the loss of life due to the dam failure. The DSO-99-06 is developed earlier than the LSM. However, both have same objective which is to estimate the loss of life. With the recent technology, LSM is one of the tools that can simulate the dynamic interaction between the 2D hydraulic model and the physical interactions of the objects within the flood wave. With the reference to the Geographic Information System (GIS), more accurate data can be obtained. Both tools have advantages as well as limitations which can be improved in the future. Table 3 shows the benefits and limitation of both models.

Table 3: Benefits and limitation of the tools

\begin{tabular}{|c|c|c|c|c|}
\hline Tools & \multicolumn{3}{|c|}{ Jimitations } & Limitations \\
\hline $\begin{array}{c}\text { DSO-99- } \\
06\end{array}$ & iii. & $\begin{array}{l}\text { Three variables as } \\
\text { dominant roles in } \\
\text { dam failures; flood } \\
\text { severity, warning } \\
\text { time, warning ur- } \\
\text { gency } \\
\text { LOL relationship } \\
\text { are based on judg- } \\
\text { mental. Eg: fatali- } \\
\text { ties rate are greater } \\
\text { for areas that re- } \\
\text { ceive no warnings } \\
\text { but high severity of } \\
\text { flooding. } \\
\text { Cost to conduct the } \\
\text { study is low as in- } \\
\text { undation maps and } \\
\text { PAR information } \\
\text { are available. } \\
\text { Provides insights } \\
\text { into factors that in- } \\
\text { fluence when } \\
\text { warning initiated } \\
\text { for dam failure. Eg: } \\
\text { type of dam, drain- } \\
\text { age area of the dam }\end{array}$ & i. & $\begin{array}{l}\text { Travel times, depth } \\
\text { and velocities that } \\
\text { affects the people } \\
\text { vehicles and } \\
\text { boundaries is de- } \\
\text { termined based on } \\
\text { large scale averag- } \\
\text { es. } \\
\text { PAR (people at } \\
\text { risk) is consider for } \\
\text { the entire area of } \\
\text { inundation or for } \\
\text { large sub-grouping } \\
\text { of PAR } \\
\text { Evacuation is not } \\
\text { specifically evalu- } \\
\text { ated } \\
\text { Easy to used and } \\
\text { outlined step by } \\
\text { step, users may in- } \\
\text { appropriately with- } \\
\text { out thinking the } \\
\text { specific situations. }\end{array}$ \\
\hline $\begin{array}{l}\text { Life Safety } \\
\text { Model } \\
\text { (LSM) }\end{array}$ & iii. & $\begin{array}{l}\text { Dynamic interac- } \\
\text { tion between 2D } \\
\text { hydraulic model } \\
\text { and its agent (peo- } \\
\text { ple, vehicles, build- } \\
\text { ings) } \\
\text { DV value (depth x } \\
\text { velocity) is an in- } \\
\text { terim to define the } \\
\text { flood severity } \\
\text { Ability to develop } \\
\text { several scenario if } \\
\text { the dam failure oc- } \\
\text { cur. Eg: Warning } \\
\text { time }\end{array}$ & & $\begin{array}{l}\text { The MIKE } 21 \text { hy- } \\
\text { draulic data need to } \\
\text { be convert into } \\
\text { Telemac2D hydrau- } \\
\text { lic models. } \\
\text { The users need to } \\
\text { be critically think- } \\
\text { ing on the specific } \\
\text { situation that might } \\
\text { happen. }\end{array}$ \\
\hline
\end{tabular}




\section{Conclusion}

From the model mentioned above, since the dam failure history that happened around the world, researchers try to find their way to help in disaster plan to reduce the loss of life. With the advancement of technology lead to more detail and realistic estimation of loss of life. Although there is no perfect model in estimating the loss of life for dam failure, the effort to reduce the loss of life should be not be seen lightly.More simulations need to be carried out using real cases to ascertain the full-blown capability of LSM. Therefore, this review has provided the underpinning background of this method which could benefit the authorities in formulating evacuation plan for any vulnerable area towards flood disaster.

\section{Acknowledgement}

The authors would like to take this opportunity to recognise the strategic research partnership between Universiti Tenaga Nasional (UNITEN) and TNB Research Sdn. Bhd. in disaster risk reduction efforts for flood prone areas in the vicinity of hydropower dams. This study is supported by Tenaga Nasional Berhad Research Grant.

\section{References}

[1] Barnes, M.J., Famous Failure: Revisiting Major Dam Catastrophes, in ASDSO Annual Conference. 1992: Baltimore: Association of State Dam Safety Officials. p. 363-368.

[2] Graham, W.J., The Teton Dam Failure: An Effective Warning and Evacuation in ASDSO Annual Conference. 2008: Indian Wells, California: Association of State Dam Safety Officials

[3] Solava, S. and N. Delatte, Lessons from the Failure of the Teton Dam. 2003. 178-189.

[4] Andrew Mattox, B.H., David Coil, Erin McKittrick, Big Dams \& Bad Choices: Two Case Studies in Human Factors and Dam Failure, in Ground Truth Taking, B.H. Andrew Mattox, David Coil, Erin McKittrick, Editor. 2014.

[5] Erickson, A. Hundreds missing and several dead after huge dam collapses in Laos. The Washington Post 2018 [cited 2018 July 24]; Available from: https://www.washingtonpost.com/news/worldviews/wp/2018/07/24 /a-huge-dam-in-laos-collapsed-washing-away-6000homes/?noredirect=on\&utm term $=.400 \mathrm{dc} 76 \mathrm{f0365}$

[6] Kaur, M., et al. Ringlet dam disaster: Death and destruction on highlands. 2013 [cited 20187 June]; Available from: https://www.thestar.com.my/news/nation/2013/10/24/death-anddestruction-on-highlands-three-killed-in-bertam-valley-damdisaster/.

[7] Jonkman, S., J. Vrijling, and A. Vrouwenvelder, Methods for the estimation of loss of life due to floods: a literature review and a proposal for a new method. Natural Hazards, 2008. 46(3): p. 353389.

[8] Graham, W., A Procedure for Estimating Loss of Life Caused by Dam Failure. Vol. 6(5). 1999.

[9] Davidson, M., A. Tagg, and P. Cinque, Are There Better Ways to Quantify Flood Risk to Life?, in Australian and New Zealand Disaster and Emergency Management Conference Surfers Paradise, Gold Coast. 2014.

[10] Sättele, M., M. Bründl, and D. Straub, Reliability and effectiveness of early warning systems for natural hazards: Concept and application to debris flow warning. Reliability Engineering \& System Safety, 2015. 142: p. 192-202.

[11] UNISDR. UNISDR. Terminology. Geneva: The United Nations Office for Disaster Risk Reduction. 2017 [cited 201822 Jun ]; Available from: https://www.unisdr.org/we/inform/terminology.

[12] Ayyub, B.M., Risk Analysis in Engineering and Economics 2007 CRC Press. 600

[13] Smith, L., et al., Assessing the utility of social media as a data source for flood risk management using a real- time modelling framework. Journal of Flood Risk Management, 2017. 10(3): p. 370-380.
[14] Sun, Y., et al., Theory and application of loss of life risk analysis for dam break. Transactions of Tianjin University, 2010. 16(5): p. 383-387.

[15] Lumbroso, D., M. Di Mauro, and D. Ramsbottom, Recent developments in loss of life modelling for flood defence and dambreak risk assessments. 2008.

[16] Johnstone, W., et al. Architecture, modelling framework and validation of BC hydro's virtual reality life safety model. in This symposium is one of the major opportunities for engineers and scientists to meet in order to report on and discuss ways in which hydraulic and stochastic analyses can be integrated in an effective and useful manner in order to meet these challenges. In this context it is important to note that the move, in which the first eight in this series of symposia have played a pivotal role, over the last twenty years towards more. 2005.

[17] Herzog, M.A., Practical dam analysis. 1999: Thomas Telford.

[18] Morris, M., Concerted Action on Dambreak Modelling-CADAM. 2000.

[19] Duane M. McClelland, D.S.B., ESTIMATING LIFE LOSS FOR DAM SAFETY RISK ASSESSMENT-A REVIEW AND NEW APPROACH, in Institute of Water Resources, U.A.C.o. Engineers, Editor. 2002.

[20] Lence, B., et al., Development of a life safety model to estimate the risk posed to people by dam failures and floods. Vol. 21. 2011.3143. 